\title{
Yeniden Çeviri Hipotezi Bağlamında Çeviri İntihali
}

\section{Translation Plagiarism in the Context of Retranslation Hypothesis}

\author{
Betül Parlak Cengiz ${ }^{1}$ (1)
}

'Haliç Üniversitesi, Fen-Edebiyat Fakültesi, Mütercim Tercümanlık Bölümü, İstanbul, Türkiye

ORCID: B.P.C. 0000-0002-4577-8890

Sorumlu yazar/Corresponding author: Betül Parlak Cengiz (Prof. Dr.),

Haliç Üniversitesi, Fen-Edebiyat Fakültesi, Mütercim Tercümanlık Bölümü, İstanbul, Türkiye E-posta: betulparlak@yahoo.com

Başvuru/Submitted: 26.06 .2019 Kabul/Accepted: 20.06 .2020

Atıf/Citation: Cengiz-Parlak, B. (2020). Yeniden çeviri hipotezi bağlamında çeviri intihali. Istanbul Üniversitesi Çeviribilim Dergisi - Istanbul University Journal of Translation Studies 12, (2020), 17-28.

https://doi.org/10.26650/iujts.2020.12.0002

\section{öz}

Bu çalışmanın temel hedefi, Antoine Berman (1990), Antony Pym (1998), William Chesterman (2000), Kaisa Koskinen \& Outi Paloposki (2010), Şehnaz Tahir Gürçağlar (2008) başta olmak üzere, pek çok çeviribilim araştırmacısının, çeşitli yönleriyle değinip ele aldığı yeniden çeviri hipotezinin somut bir olgu olarak karşımıza çıkan "çeviri intihali" meselesine hiç değinmiyor olmasını tartışmaya açmaktır. Yeniden çeviri, yukarıda isimlerini andıklarımız da dahil pek çok çeviribilim kuramcısı tarafından tartışılmış ve çoğu kez erek kültürde ortaya çıkan bir "gereklilik" nedeniyle doğal olarak meşru ve kabul edilebilir bir olgu olarak görülmüştür. Ancak, kültürümüzde "yeniden çeviri" olarak adlandırılabilecek pek çok metnin çeviri intihali sonucunda ortaya çıktığını gösteren çeşitli görgül çalışmalar (Parlak: 2008, Gürses: 2008, Çelik: 2008, Evirgen: 2008) da bulunmaktadır. Bu çalışmaların da ışı̆̆ında, yeniden çeviri hipotezinin, somut bir çeviri gerçekliği olarak "çeviri intihalini" görünmez mi kıldığı sorusunu da tartışmaya açmayı hedefleyen bu makalenin nihai bir sonuç ya da çözüm iddiası bulunmamaktadır. Bu çalışmanın başlıca amacı, yeniden çeviri hipotezinin sadece bizim kültürümüzde değil pek çok başka kültürde de görülen "çeviri intihalini" (Turell: 2004, Leighton: 1994) görmezden gelmesinin, bu olgunun çeviribilim literatüründe yer bulmasını zorlaştırıp zorlaştırmadığını sorgulamak ve çeviri etiği açısından intihal ile yeniden çeviri olgusunun sınırlarının nasıl çizilebileceğine dair bir öneride bulunmaktır.

Anahtar kelimeler: Yeniden çeviri hipotezi, Çeviri intihali, Çeviri etiği

\section{ABSTRACT}

This study focused on the absence of translation plagiarism in the context of a retranslation hypothesis that has been discussed and considered with different aspects by many scholars, including pioneering ones such as Antoine Berman (1990), Antony Pym (1998), William Chesterman (2000), Kaisa Koskinen \& Outi Paloposki (2010), and Şehnaz Tahir Gürçağlar (2008). It was strange to discover that when scholars consider retranslation as a factual reality that they do not discuss and evaluate translation plagiarism in the framework of this hypothesis. Retranslation was and is usually considered as a "necessity" for "filling a gap" and "complete an incompleteness". From this point of view, it is a legitimate and acceptable translation activity that emerged with the claim of renewing an old translation. Nevertheless, it is scarcely discussed as translation plagiarism in this context. However, there are many other empirical studies showing that some texts which could easily be called "retranslation" in Turkish are "plagiarized 
translations" (Parlak: 2008, Gürses: 2008, Çelik: 2008, Evirgen: 2008) as well in other languages and cultures (Turell: 2004, Leighton: 1994). In light of these studies, this article aimed to question if the retranslation hypothesis renders "translation plagiarism" invisible, arguing that retranslation is a necessary activity to present a "new reading experience" of source text. My main question was if the retranslation hypothesis with its silence about translation plagiarism renders it difficult to discuss translation plagiarism in translation studies literature. As a conclusion, I would argue how can the limits be drawn between translation plagiarism and retranslation phenomenon in terms of translation ethics. Keywords: Retranslation hypothesis, translation plagiarism, translation ethics 


\section{Giriş}

Her çeviri yeni bir okuma deneyiminin ortaya konulması ve paylaşılmasıdır. Bir metnin daha önce çevrilmiş olması, onun tekrar çevrilemeyeceği ya da çevrilmemesi gerektiği anlamına gelmez. Bir kaynak metni, yeni bir okuma deneyimi ile gözden geçirdiğini iddia eden herkes daha önce çevrilmiş bir metni yeniden çevirebilir ve okuma deneyimini başkalarıyla paylaşabilir.

Betimleyici açıdan baktığımızda, yeniden çevirinin bir ürün olarak, önemli bir çeviri gerçekliği ve çoğu kez belki de "kaçınılmaz" bir kültürel olgu, bir çeviri eylemi olduğunu gözlemleriz. Hepimizin bildiği gibi, betimleyici çeviribilimin en önemli görgül veri kaynaklarından olan karşılaştırılabilir metinler (kaynak metin ve çevirileri) yeniden çevirilerin de katkıda bulunduğu geniş bir araştırma ve inceleme bütüncesi oluşmasına katkıda bulunmaktadır. Betimleyici çeviribilim çalışmaları, karşılaştırmak için seçilen metinlerde benzerlik ve farklılıklar üzerinde durarak, belli bir çevirinin yapıldığı dönem, o dönemde hâkim olan dilsel ve kültürel normlar, baskın ideolojik yaklaşımlar ve çevirmenin kimliği üzerine çeşitli varsayımlar yapılmasını sağlayacak gözlemler üretir. Kuşkusuz bu gözlemler, kültür ve zaman bağımlıdır tıpkı karşılaştırılan metinlerdeki çeviri kararları gibi.

Ancak, kaynağını Antoine Berman'ın ünlü makalesinden ${ }^{1}$ aldığı söylenen ve temel argümanı Alman romantizmine kadar uzanan yeniden çeviri hipotezinin çeviribilim literatüründe yorumlanış biçimi bu kültür bağımlılığı görmezden geliyor gibidir. Temel iddiası "yeniden çevirilerin, kaynak metinlere ilk çevirilerden daha yakın oldukları" önermesine dayanan YÇ hipotezine göre, "ilk çeviriler alıcı kültürde kabul görmek için daha erek odaklı bir yaklaşımla" okura sunulmuşlardır. Kuşkusuz, bir "yazar" ya da "eser” somut bir kültür varlığı olarak herhangi bir erek kültürde kabul görüp yer edindikten sonra "yabancılığını fark ettirmek" çok daha kolay olabilir. Bu bağlamda "kaynak metin" yerine, "yazar/eser" sözcüklerini kullanma nedenim, herhangi bir erek kültüre çeviri yoluyla ithal edilen somut ve soyut bir "değerin” varlığına vurgu yapmak içindir. Metin aslında okurla ilişkisini okuma düzeyinde kuran "tembel bir mekanizma iken" (Eco, 1979), “eser” ya da "yazar" metinden çok daha fazlasını aktaran, yanmetinlerle haklarında zaten pek çok bilgi sunulmuş olan birer “değer" olarak hem kaynak kültürde hem de erek kültürde varlıklarını sürdürürler. Bu nedenle de erek kültürde kabul edilmelerini sağlayan bir zemin, metnin içeriğinden bağımsız olarak yazarın kimliği ve eserin niteliği (ünü, aldığı ödüller vb.) açısından zaten oluşmuş hale gelir. Tam da bu nedenle erek kültürler çoğu kez, aktarılan metni içeriğinden bağımsız olarak, makro ölçekte egemen olan kültürel ve ideolojik normlar doğrultusunda zaten kabul edip benimsemeye hazır haldedirler.

1 "Yeniden çevirilerin neden gerekli olduğu sorusu genellikle kendisi de fazlasıyla gizemli olan bir olgu temelinde açıklanmaya çalış1ır. Özgün metinler sonsuza dek (onlara olan ilgimizden, onların kültürel açıdan bize yakınlığı ya da uzaklı̆̆ından bağımsız olarak) genç kalırken, çeviriler, işte onlar, yaşlanırlar [...] Hiçbir çeviri "asıl" çeviri olduğunu ileri süremeyeceğine göre yeniden çevirinin olasıllğı ve gerekliliği çeviri ediminin kendi yapısının içinde bulunur." Antoine Berman, "La retraduction comme espace de la traduction." Palimpsestes. 4: 1-7, 1990. Alınt1 kaynağı Ayşe Ece, Edebiyat Çevirisinin ve Edebiyat Çevirmeninin İzinden, İstanbul: Sel Yayıncılık, 2010, s.47. 


\section{Hipotezin Güvenilirliği}

YÇ hipotezinin test edilmesini ve bazı durumlarda da makul kabul edilmesini sağlayacak örnekler bulunmaktadır. Ancak, alıcı kültürden, kaynak metnin yazarından, metin türünden, çevirinin yapıldığı zamandan ve söz konusu zamanda hüküm süren çeviri normları ve ideolojik tutumlardan bağımsız olarak her dil çifti, her kültür ve her türlü eser için genellenebilir bir çerçeve sunduğu söylenemez (Desmidt: 2009). Örneğin bir yeniden çeviri cenneti olan ülkemizde, eski çevirilerin hepsinin erek odaklı, yenilerinin ise kaynak odaklı bir yaklaşım sergilediklerini iddia edemeyiz. Nitekim bu alanda yapılmış çeşitli çalışmalar da bu hipotezin genellenebilir bir önerme sunmadığını göstermiştir (L. Deane: 2011).

Yeniden çeviri konusunda ortaya atılan bazı görüşler, metin türü ayrımını gözler önüne sermiştir ve bu çeviri pratiğinin daha çok yazınsal metinler özellikle de edebiyat kanonunun yazınsal değeri yüksek eserleri ya da yazarları söz konusu olduğunda daha fazla uygulandığını vurgulamışlardır. Aynı şey çocuk klasikleri için de geçerlidir. Bu durum başka metin türlerinde bu uygulamanın gerçekleşmediği anlamına gelmez. Ancak, yukarıda andığımız metin türlerinde daha sık karşılaşılan bir durum olması YÇ olgusunun, "eser/yazar" dolayısıyla "değer" paradigmasına bağlı̆̆ını da gösterir.

Nitekim Susam-Sarajeva'nın çalışması (2000), 1975-1990 yılları arasında Türkçeye çevrilen ve yeniden çevrilen Roland Barthes metinlerinin erek dil ve kültürde yeni bir yazın eleştirisi söylemini yerleştirme mücadelesi sonucu ortaya çıktıklarını gösterir. Söz konusu örnekte belli bir iddiası olan çevirmenler, yazarlar ve yazın adamları aktif eyleyenler olarak yer alırlar ve göstergebilimsel yazın eleştirisinin temel metinleri sayılan Barthes metinlerinin erek kültüre "ithali" sırasında "doğru" ve "bağlama uygun" anlaşılmaları mücadelesinin eşzamanlı eyleyenleri olarak aynı zamansal çerçeveyi paylaştıkları söylenebilir.

\section{Yeniden Çeviri ve Diliçi Çeviri: Sunırlar Nerede?}

Sadece yukarıdaki örnek bile yeniden çeviri hipotezinde sıklıkla kullanılan bir gerekçe olan, önceki çevirilerin dilinin eskimesi ve tam da bu nedenle erek kültürün gereksinimlerine yanıt verememesi gibi bir gerekçenin bütün yeniden çeviriler için genelleştirilemeyeceğini söylememize izin vermektedir. Artzamanlı yeniden çeviriler eskilik ve buna bağlı yenilenme gereksinimi iddiasının gerekçelendirilebilirliğini kolaylaştırırken, bir başka sorunu da gündeme getirir. Erek kültürde, belli bir yazarın büyük bir ihtimalle yazınsal değer taşıyan ve dünya edebiyat kanonunda belli bir yeri olan bir eserinin zaten en az bir çevirisi bulunmaktadır. Diyelim ki bu çeviriler ilgili kişilerce bilinip, kullanılmakta ya da okurların kolayca erişebileceği şekilde piyasada bulunmaktadır. O halde bu tür çevirilerin sadece dilleri "eskidiği” için yeniden çevrilmesine karar verildiğinde ortaya çıkan ürün bir yeniden çeviri midir yoksa diliçi çeviri mi yapılmaktadır?

İlk sorudan yola çıkarsak, zaten var olan bir çeviriyi dilsel açıdan eşanlamlılık düzeyinde yenilemekle kısıtlı bir eylemin "dil içi”" bir işlem olduğunu söylemek yanlış olmaz. Nitekim çeviri intihali konusunda yaptığımız çalışmalar, intihal oldukları anlaşılan metinlerin sadece 
“sözcük” düzeyinde dilsel yer değiştirmeler içerdiğini, bu yer değiştirmelerde eski ve görece “anlaşılmaz” görünen sözcüklerin yerini daha yenilerinin aldığını göstermiştir. ${ }^{2}$ Dili içi çeviriyi eskiyen dili, eşanlamlılık düzeyinde yenilemekten ibaret bir işlem olarak görürsek, bu gerekçe ile yapılmış yeniden çevirilerin hangi "kaynak metne" dayandıklarını ileri sürebiliriz? ${ }^{3}$ Dilinin eskidiği iddia edilen daha önce yapılmış bir çevirinin dili, görece "yenilendiğinde" yapılan işlemin bir yeniden çeviri olduğunu ileri sürmek zor görünmektedir. Ayrıca yazma ediminde yeri olan, kopyalama, yeniden yazma, adaptasyon, gözden geçirme ve yayına hazırlama kavramları açısından da durumu değerlendirmek gerekmektedir. Bir başka çeviriye dayanan ve bu nedenle kaynak metin ile ilişkisi sınırlı olan ya da daha önce yapılmış çeviri/çeviriler üzerinden kurulan bir kaynak metin okuma işlemine çeviri denebilir mi?

Bu tür bir ilişki ile gerçekleşen bir "dilsel düzenleme (örneğin sözdizimsel olabilir) ya da sözcük düzeyinde yenileme" işleminin hangi ölçüde yeniden çeviri olarak değerlendirilebileceği kuşkulu görünmektedir.

\section{3. Çeviri İhtihali}

İntihal ya da metin düzeyinde aşırma dediğimiz uygulamanın, aslında yazınsal esinlenme, metinlerarasılık, gönderme, alıntılama, açımlama vb. metin kurma teknikleriyle arasındaki sınırın görünürde çok kolay çizilememesi nedeniyle yeniden çeviri hipotezi çeviri intihalini söyleminin bir parçası haline getiremiyor olabilir. Betimleyici yöntemi benimseyen çeviribilim araştırmacıları, bu metin kurma teknikleri açısından çeviri intihali olgusunun nasıl değerlendirilebileceğine yönelik sorunlar yaşıyor olabilirler. ${ }^{4} \mathrm{Bu}$ durumda konuyu biraz daha netleştirmek için, çeviri ürünün, hangi türden olursa olsun, bir fikri ürün olduğunu ve ürünü ortaya koyan kişinin fikri emeğini, öznel okuma ve alımlama biçimini, içinde yaşadığı tarihi döneme özgü okuma biçimlerini içerdiğini hatırlatmak gerekir. Ancak, geleneksel olarak

2 Sabri Gürses "Çeviri İntihali: Kültürel Ekosistemin Paraziti”, Çeviri ve Çevirmenliğin Etik Sorunları (Çeviri Etiği Toplantısı 7-8 Aralık 2006 Bildiri Kitabı) içinde, İstanbul: İstanbul Üniversitesi Yayın No: 4739, ISBN No: 978-975-404-802-5, s. 133-146, 2008.

Betül Parlak, "Çeviri İntihalleri Bağlamında İlahi Komedi”, Çeviri ve Çevirmenliğin Etik Sorunları (Çeviri Etiği Toplantısı 7-8 Aralık 2006 Bildiri Kitabı) içinde, İstanbul: İstanbul Üniversitesi Yayın No: 4739, ISBN No: 978-975-404-802-5, s.147-160, 2008.

Özge Çelik, "Robinson Crusoe'nun Türkçe Çevirileri Bağlamında Çeviride İntihal Olgusu”, Çeviri ve Çevirmenliğin Etik Sorunları (Çeviri Etiği Toplantısı 7-8 Aralık 2006 Bildiri Kitabı) içinde, İstanbul: İstanbul Üniversitesi Yayın No: 4739, ISBN No: 978-975-404-802-5, s. 161-170, 2008.

Şilan Evirgen, "Çeviride İntihalin Saptanması: Örnek Olarak Montaigne'in "Denemeler"inin Çevirileri”, Çeviri ve Çevirmenliğin Etik Sorunları (Çeviri Etiği Toplantısı 7-8 Aralık 2006 Bildiri Kitabı) içinde, İstanbul: İstanbul Üniversitesi Yayın No: 4739, ISBN No: 978-975-404-802-5, s. 171-177, 2008.

Ayrıca bkz. ÇEVBİR-YAYBİR İntihal İnceleme Komisyonu Sonuç Raporu, Mart-Aralık 2007, http://www. cevbir.org/yeni/index.php/tr/intihalkomrap, Erişim [10.11.2013]

3 Bu noktada diliçi çeviri kavramının da tartışılmaya açılması gerektiğini ama bu makalenin konusu ve sınırları açısından bu bağlamda tartışma dışı bırakıldığını belirtmek isterim.

4 Bkz. Kevin Perromat Augustin (2011), "Plagiarism: aesthetics or contemporary movement? [online article], 452F Electronic journal of literatüre and comparative literatüre, 5, [Consulted on:18/11/13] http://www.452f. com/pdf/numero05/perromat/05_452f_perromat_trad_en.pdf 
“sadakat”, "doğruluk”, "tam karşılık” gibi kavramlara dayanan ve çeviri algısını yönlendiren hâlâ baskın bazı görüşler kanımca, somut bir gerçeklik olarak çeviri intihalinin çeviribilim literatüründe görünür olmasını engellemektedir.

Ayrıca, daha önce herhangi bir erek dile hiç çevrilmemiş bir metnin, okuma deneyimini görünür hale getiren, söz konusu metnin "ilk" okuru olan bir çevirmenin bireysel anlama deneyiminin ürünü olan çeviri metnin, kaynak metinde yer alan "değişmez, doğru bir anlamı" aktardığ 1 fikriyle hareket edildiğinde "metinlerin okurun müdahalesini bekleyen tembel mekanizmalar"5 olduğu savına dayalı okur merkezli kuramlar da dikkate alınmamaktadır. Bir metnin sadece bir tane "doğru” ve "değişmez" anlamı olduğu kabulünden yola çıkan geleneksel görüşün etkisi çeviri intihalinin de meşrulaşmasına katkı da bulunmaktadır. Yeniden çevirilerde intihal iddiasına yanıt verenler arasında yaygın görüşlerden biri de zaten "mükemmel” olan bir dizeyi/bölümü/ifadeyi yeniden çevirmeye girişmenin aptalca olacağıdır”. Bu yaygın görüşü alıntıladığımız kaynak da "çevirmenin eser sahipliği konumuna dikkat çeker ve meşru yaratıcılık ile hırsızlık arasındaki çizgiler çok açık çekilmediğinden” yakınır (LEIGHTON 1994: 69).

M. Teresa Turell'in yazınsal çeviride intihali bir vaka çalışması 1şı̆̆ında konu alan makalesi de intihal ile suçlanan çevirmenin "kusursuz" çözümü almakta bir beis görmediğini de göstermektedir (2004). Üstelik intihal ile suçlandığında yukarıdaki gerekçe ile kendini savunan çevirmenler de bulunmaktadır. O halde biz çeviribilim araştırmacıları olarak, yeniden çeviri hipotezinde örtük olarak kaynak metinde ve metnin çeşitli çeviri birimlerinde "değişmez" bir anlam olduğu ve bunun da bazen "mükemmel" biçimde aktarılabileceği gibi bir argüman olup olmadığını sorgulamalıyız. Bence hipotez böyle bir iddia içermemektedir, içeriyor olsa, güvenilirliği ve test edilirliği daha da problemli hale gelir. Çünkü böyle bir iddia okuma ve anlama deneyiminin “öznelliği, tarihselliği, kültür ve değer bağımlılığı” gibi yorumbilgisel temel kategorilere uygun değildir.

Bence yeniden çeviri hipotezi, ilk çevirilerin “erek odaklı”, daha sonrakilerin ise, erek kültür okurlarının metin ve yazarla tanışıklığı sağlandıktan sonra daha "kaynak odaklı" olduğu/ya da olabileceği iddiasıysa, tam da yukarıda söz ettiğimiz “değişmez anlam” kabulüne örtük bir itiraz gibi görünmektedir. Üstelik genelde, bazı çeviri birimler açısından mükemmel sayılan çözümler, genelde “erek odaklı” dilsel çözümlerdir, yabancıllı̆̆ı azaltmaya yönelik, erek kültürde kabul edilebilirliğini sağlamaya yönelik çözümler olarak değerlendirilebilir.

YÇ hipotezi bu değişmez anlam iddiasını içermese de hipotez acaba bu haliyle çeviri intihalini meşrulaştırmak için bazı "işbilirlerin” kullandığg bir argümana dönüşebilir mi? Bu temel kaygı ve sorundan yola çıkarak "çeviri intihali” konusuna geçmek istiyorum.

\section{4. İntihal Nasıl Anlaşıılır?}

Çeviribilim literatürünün ya da intihal konusuyla ilgili “bilirkişis” raporu yazacak olanların sıklıkla üzerinde durduğu nokta, kanıtların nasıl sağlanacağı ve nasıl değerlendirileceği ile

Bkz. Umberto Eco, Lector in Fabula, Milano: Bompiani, 1979. 
ilgilidir. Günümüzde bilgi teknolojilerinin gelişmesiyle, ödev, yazınsal eser, bilimsel eser vb. metinlerde intihali tespit eden bilgisayar programları oluşturulmuştur. Bu programlar benzerlikleri saptayarak, sayısal oran verebilmekte ve bu oranlara göre de intihal şüphesi ya da somut intihal kanıtının nasıl niceliksel veri ile aktarılabileceğini belirlemektedirler (Bkz. Turell, 2004). Nitekim ülkemizde de bu konuda TÜBİTAK destekli bir proje yürütülmektedir. ${ }^{6}$ Konuyla ilgili gazete haberine göre bu proje kapsamında seçilen örnekler tarayıcıdan geçirilip metne dönüştürülmüş ve elde edilen bulgulardan yola çıkarak karşılaştırmalı metin analizi için hangi bilgisayar programının daha iyi sonuç vereceği üzerinde çalışılmaktadır:

Çalışmayı 2015'te tamamlamayı planlayan ekip, sayısal veriler elde etmek, metinler arasındaki benzerlik oranlarını saptamak üzere sözcük ve sözdizimi düzeyinde incelemeler yürütüyor. Bunun dışında, makinelerin yeterince algılayamayacağı nadir sözcük ve ifadelerin kullanılması, tekerrürlerin yakalanması, aynı sözcük için eşanlamlı ya da öz Türkçe sözcüklerin kullanılması gibi benzerlikleri saptamak üzere semantik bir analiz yapıyor: "Burada, bu tip çalışmalarda kullanılmaya başlanmış olan adli dilbilim devreye giriyor. Ayrıca çok açık benzerlik ya da örtüşmelerde sosyolojik, bağlantısal bir analiz gerekiyor. Yayınevi, metin sahibi olarak görünen kişi, matbaa vb. kurumlar arasındaki ilişkiyi çözmeye çalışıyoruz.

Haberden anlaşıldığı kadarıyla niceliksel veriye dayalı bir kanıtlama sistemi geliştirmeye çalışan bir proje ile karşı karşıyayız. Niceliksel veri, daha sağlam bir kanıt görünse de üçüncü bölümde ele aldığım, fikri ürün ve yaratıcılık bağlamlarını değerlendirme dışında bırakmamak gerektiğini düşünüyorum. Niceliksel veri, bilgi teknolojileri yoluyla elde edildiğinde kaçınılmaz olarak benzerlik içeren dilsel birimlerin de (sayı ve işaret sıfatları, bağlaçlar, fiil çekimleri vb.) kanıtlar arasında yer almasina neden olabilir.

Oysa bir çevirmenin yaratıcılığının ürünü olarak ortaya çıkmış ve pek çoklarınca "mükemmel" çözüm ya da karşılık gibi görünen bazı dilsel birimler (ya da çeviri birimler), niteliksel veri kategorisinde yer alabilir ve daha somut bir kanıt sunabilir. Örneğin, Madam Bovary, çevirilerini intihal açısından incelediğimde, özgün diyebileceğim 3 ya da 4 farklı çeviri vardı, diğerleri ise, bu metinleri kaynak metin olarak kullanan aşırmalar olarak görünüyordu. Kimin hangi çeviriden "aşırdığını” anlamak niteliksel kanıtlar ile mümkün olmuştu. Örneğin, Tahsin Yücel dışında, "tavşanlık” sözcüğünü kullanan çevirmen yoktu ve bu sözcük onun çevirisinden yapılan intihali görmeyi kolaylaştırmıştı. Aynı şekilde, bir önceki çevirinin yazım hatalarını ya da yanlış anlamaları tekrarlamak, yabancılaştırma ya da yerlileştirme stratejilerini birebir izlemek de kanıtlar arasında sayılabilir.

\section{5. Çeviri İntihali ile Nasıl Mücadele Edilebilir?}

YÇ hipotezi, pek çok açıdan neden yeniden çeviri yapıldığını bize söylemektedir. Bu konuda kısa bir literatür taraması olası nedenler açısından fikir verecektir. Ancak, YÇ literatüründe üzerinde fazlaca durulmayan noktalar, somut piyasa gereksinimleri, yayıncılık endüstrisinin

6 http://www.zaman.com.tr/kultur_100-temel-eser-kitaplari-intihal-ceviriyi-artirdi_2175558.html 
temel kaygıları, pazar ve pasta payı gibi daha ekonomik ve global bileşenlerdir. Çünkü hipotez genelde çeviri metnin niteliği üzerine odaklanmakta, bir ürün olarak çeviri metnin dilsel ve anlamsal bileşenleri tartışmaktadır. Belki bu noktada tartışmamız gereken pazarlanabilir bir ürün olarak "söz konusu” çevirinin piyasa değeridir. Konuyla ilgili literatür yeniden çevirilerin büyük oranda edebiyat kanonunda önemli bir yere sahip yazınsal eserler söz konusu olduğunda yapıldığını göstermektedir. O halde bu noktada metnin içerik değerinden çok, "sembolik" değeri pazar için önemli olmaktadır. Yayıncılık piyasası, belli bir sembolik değeri olan bir dünya yazarının ve/veya bir yazınsal "şaheserin" hemen her zaman satabileceğini bilir. Yayıncı, eser sahibinin ölümünün üstünden 70 yıl geçmiş ise kaynak metne telif ödemediği için daha ucuza mal ettiği ve satış garantisi olan bir ürüne sahip olacaktır. Peki, neden "yeniden çevirtilmesi”" gerekir? Bunun çeşitli nedenleri bulunmaktadır:

- Çevirmene telif ücreti ödememek için, eski çeviriler kaynak metin olarak kullanılırsa, daha da ucuz bir ürün ortaya çıkar.

- Genelde daha önceki çeviriler bir başka yayınevi tarafından telifi ödenerek kullanıldığı için yeniden çevirtmek gerekebilir.

- Daha önce yapılmış çeviriler aradilden yapılmış olabilirler, kaynak dilden çevrilmesi gerektiği iddiası ile yeniden çevirtilebilir.

- Daha önce yapılmış çeviriler eksik olabilir, kısaltılmış olabilir "eksiksiz” çeviri iddiası ile yeniden çevirtilebilirler.

Belli bir erek kültürde, bir yazarın ya da bir eserin genelde her zaman kâr getiren bir piyasa değeri varsa, yani okur kitlesi için vazgeçilmez ve "klasik" kabul ediliyorsa, yukarıdaki gerekçelerden ilk ikisi yeniden çeviri için zemin hazırlar. Son iki gerekçe ise, daha çok metnin içerik düzeyi ve içerik değeri ile ilgilidir. Bu durumda, söz konusu değerin yeni çevirmen ve yeni yayınevi tarafından nasıl oluşturulduğuna bağlı olarak "gerekçelendirilmiş" yeniden çeviriler ortaya çıkabilir. Gerekçelendirilmiş yeniden çeviriler, üzerinde en az intihal gölgesi olanlardır, çünkü yeni çevirmen bir iddia ile yola çıkar ve bu iddiası doğrultusunda verdiği çeşitli kararları bazı yanmetinlerde okurla paylaşır. Önsözler, röportajlar vb. türünde metinler yeni çevirinin hem tanıtılmasına hem de gerekçelendirilmesine yardımcı olur. Böylece çok önemli iki şüpheyi de ortadan kaldırmış olur. Bu şüpheler aşağıdaki sorularda dile getirilmeye çalışılmıştır:

- Belli bir okuma deneyiminin sonucunda, yaşadığımız dönemden daha önce kendi dilimizde oluşturulmuş bir çeviri metin, bizlerin kaynak metni "okuma deneyimini”" yönlendirip kolaylaştırmaz mı?

- Özellikle de bir önceki okuma deneyimi ile hesaplaşmayan ve sorgulamayan "sözde" yeniden çeviri gibi görünen metinler, böyle bir pratik ile başkasının "okuma deneyimini”" çalmazlar mı? 
Yeniden çeviri hipotezinin örtük olarak daha iyi bir metin ortaya çıkmasını sağlayan bir eylem olarak yeniden çeviriye baktığını, ürün olarak da "hataları" düzeltilmiş bir metin ortaya koyduğunu söyleyebiliriz. Bu durumda söz konusu metin, önceki çevirinin düzeltilmesi, tekrar yayına hazırlanması, yeniden yazılması ya da kısmen kopyalanması gibi eylemleri de içerebilir.

Bir yeniden çeviri, çeşitli çeviri araştırmacılarının dile getirdiği gibi eski çeviriyi daha iyi hale getirmek iddiasıyla yola çıktığında, önceki çeviri konusunda detaylı bir fikri olan, ona meydan okuyan, ondan farklı bir metin ortaya koyma iddiasında olan bir çevirmen ile karşılaşacağımız düşünülebilir. Bu durumda bile, bir başka okuma deneyimi ile hesaplaşmayı içerdiğinden, eski çeviriden bir yararlanma, belli ölçüde bir kullanma söz konusu değil midir?

Nitekim Chesterman'ın yeniden çeviri ile ilgili aşağıdaki saptamalarından ilk ikisi (2000: 15-27) yukarıdaki gözlemi doğrular niteliktedir:

- Daha sonraki çevirmenler daha önceki çevirilere eleştirel bir bakış açısıyla yaklaşırlar ve onları daha iyi hale getirmeye çalışırlar,

- Daha önce yapılmış bir çevirinin varlığı yenisinin alımlanmasını kolaylaştırır.

- Erek dil gelişmiştir ve çevirmenin daha özgür bir hareket alanına sahip olmasını sağlar.

- $\quad$ Erek kültürün çeviri normları yumuşamıştır ve kaynak metne daha yakın bir çeviri yapılmasına izin verir. (Aktaran Desmidt, s.678)

İntihal şüphesinden arınmak isteyen bir yeniden çeviride, önceki çeviri/lerin çevirmenleri, onların emeği, okuma deneyimi çevirmen önsözünde anılmalıdır. Yeniden çeviri yapan çevirmen, kendi metninin farkını ve özgünlüğünü ortaya koymalı, kendi okuma deneyimini gerekçelendirmeli ve önceki çevirilerle söyleşmelidir. Yukarıda sıraladığımız maddelerden yola çıkarsak, birinci madde de belirtildiği gibi, eğer ortada bir eleştiri varsa, eleştirel bakış açısıyla eski metnin nerelerinin, neden ve hangi açıdan daha iyi hale getirildiği açıklanmalıdır. Bu noktada "-meli, -malı" gibi ifadelerle, "ahlak bekçiliği” yaptığım ya da kuralcı bir çeviribilim anlayışı benimsediğim sonucu çıkmasın. Ülkemizde ve pek çok başka ülkede, Fikir ve Sanat Eserleri Kanunu'na göre çeviriler, işleme eser sayılmakta ve eser sahibinin hususiyetini taşımaktadırlar. Tam da bu nedenle, çeviri intihali, fikri ürün hırsızlığı konusu olarak mahkemelere taşınabilmekte ve bizler çeviri alanı akademisyenleri olarak bilirkişilik yapmak zorunda kalabilmekteyiz. O halde bir yeniden çeviri önceki çeviriler ile ilişkisini önsözünde belirterek yasal açıdan da kendini aklayabilecek duruma gelmelidir. Ayrıca Chesterman'ın sıralamasında yer alan ikinci maddeye tekrar bakarsak, "daha önce yapılmış bir çevirinin varlığının yenisinin alımlanmasını" kolaylaştırdığı saptamasını görürüz, bu saptama yerinde ve doğru bir duruma işaret etmektedir. Çeviri etiği açısından yeniden çeviri yaptığını iddia eden çevirmen, kaynak metni anlamasını kolaylaştıran önceki çeviri ya da çevirileri anarak, meslektaşları ve mesleğine yönelik sorumluluğunu da yerine getirme firsatı bulacaktır.

Tekrar hatırlatmam gerekirse etik yönerge ya da kuralcı bir yaklaşım getirme gibi bir iddiam yok, ancak, yukarıda açıklamaya çalıştığım çeşitli gerekçeler, somut veriler ve olaylar ışığında, yeniden çeviri hipotezinden söz edilirken, “çeviri intihali” konusunun hiç 
dile getirilmemesini sorunlu bulduğumu bir kez daha belirtmek isterim. Çeviribilimcilerin kuramsal açıdan birbirine bu kadar yakın iki olgudan söz ederken "yeniden çeviri” hipotezini metin düzeyinde yeni okuma deneyimlerine olanak tanıyan ve bu deneyimlerin okurlarla paylaşılmasını cesaretlendiren, var olan okuma deneyimlerini çeşitlendirip zenginleştiren bir pratiği yorumlamak için kullanırken, çeviri eyleminin, eyleyenin ve onun ilk okuma deneyiminin "yasal” ve "kültürel” statüsünü tartışmaya dâhil etmemeleri, çeviri etiği açısından çok sorunlu bir uygulama olan intihali cesaretlendirebilir.

\section{Sonuç}

Chesterman'ın çeviri etiğinden söz ederken kullandığı doğruluk ve güven değerleri açısından intihal ve yeniden çeviri olgusuna bakıp, söz konusu değerler açısından çeviri intihalinin YÇ hipotezinde yer alıp alamayacağını sorgulamayı öneriyorum.

Chesterman, çeviri normlarının altında bulunan değerleri sorgulayarak ve tartışarak çeviri etiği meselesini ele alır. Bu bağlamda ele aldığı değerlerden biri de ilişki normuna hâkim değer olan doğruluk değeridir. İlişki normuna göre, çevirmen, kaynak ve erek metin arasında uygun ilişkiyi sağlayıp koruyacak şekilde hareket etmelidir (2000b:178). Çeviribilim literatüründe bu ilişkinin aynılık değil de benzerlik ya da yakınlık terimleriyle düşünülmesinin daha doğru olacağına dikkat çekilir. Chesterman, hepimizin bildiği gibi geleneksel olarak kaynak ve erek metin arasındaki ilişkinin önce sadakat ve bağlılık daha sonraları da eşdeğerlilik kavramıyla tartışılmaya başladığına dikkat çeker ve tümü kapsayıcı bir eşdeğerliliğin imkânsızlığı nedeniyle çevirmenin sadakatinin de imkânsızlığını vurgular. Tam da bu nedenle kusursuz bir çeviri ya da anlama olduğunu iddia edemeyiz. Çeviri intihalini meşrulaştırmaya çalışanlar ise, kaynak ve erek metin arasında kaçınılmaz bir "sadakat” ilişkisi olduğuna dayalı bir anlayış ile hareket ettiklerinden, "sahte bir doğruluk" ilişkisine kurgulayarak aşırma eylemlerinin anlaşılmayacağını düşünüyor olabilirler. Nitekim yaptığımız incelemelerde klasik eserlerin çevirisi alanında ortaya çıkan intihallerde ünlü ve başarılı çevirmenlerin metinleri kaynak metin olarak kullanılmıştır. Bu metinlerin "kusursuz sadakat" ilişkisini sağlamış oldukları varsayılmış olabilir. Oysa sadakat Chesterman'ın bakış açısıyla ilişki normunda hâkim değeri kavramsallaştırmak için uygun bir seçim değildir. İlişki normu dilsel bir norm olduğundan, iki metin yani iki dilsel kendilik (varlık) arasındaki ilişkinin doğası ile ilgilidir. Dolayısıyla bir metni oluştururken karşımıza çıkan tüm kısıtlamalara, çevirinin, zaten var olan bir başka metin ile belli bir biçimde ilişkili olma kısıtlaması da dâhil olur. Çeviriler kaynak metinleriyle kabul edilebilir geniş bir çeşitlilik içinde ilişki içindedirler, bu kabul edilebilir biçimler çok geniş bir yelpazede sıralanabilecek metin içi ve metin dışı nedenlere bağlıdır. Önemli olan bu ilişkilerin özgün metne göre durumun gerektirdiği biçimde doğru olmasıdır (2000b: 178-179).

$\mathrm{Bu}$ anlamda yeniden çeviri hipotezi, yukarıda andığımız türden bir "doğruluk” değeri içinde hareket ederken, çeviri intihali "sadakat" kavramına dayalı sözde bir doğruluk değeri ile ortaya çıkan bir eylemdir. 
Chesterman çeviri normlarında hâkim değerlerden bir diğerinin de en önemli iletişim değeri olan güven olduğuna dikkat çeker. Çeviriye dayalı bir iletişim etkinliğinde öncelikle çeviri işinin tarafları arasında güven sağlanmalıdır. İşveren, yayıncı, aracı, okurlar ve eğer hâlâ hayatta ise kaynak metnin yazarı çevirmene güvenmelidir. Pim'e göre "Çevirmenlerin birincil sadakati kültürlerarası bir alan olarak mesleklerine karşı olmalıdı’” (Alıntı kaynağı a.g.e. 181). Diğer meslektaşlarının ve kültürlerarası iletişim uzamının güvenini kazanmış olmak bu dügü̈m noktasında en önemli değerdir. Güven kaybetmenin güven kazanmaktan çok daha kolay olduğunu da vurgulayan Chesterman bu değerle ilgili önleyici eylemin, güven kaybetmekten kaçınmak olması gerektiğini bunu sağlamanın en iyi yolunun da çevirmenin, kararları hakkında bilgi verdiği bir önsöz ile görünür hale gelmesi olduğunu vurgular (2000b: 182).

Gerçekten de çevirmenin, çeviri kararları, çeviri stratejileri, sınırlamaları, suskun kaldığ yerler ve açımlamalarıyla ilgili bilgi vermesi yayıncıların bu tür bir tutum geliştirmeleri için çevirmenleri teşvik etmeleri, çevirmene duyulan güveni arttıracaktır. Yeniden çeviri bağlamında önsözün önemi daha da belirgin hale gelmektedir. Gerekçelendirilmiş, çevirmen kararları açıklanmış, diğer çeviri ve okuma deneyimleriyle hesaplaşmış bir çeviri yeni bir okuma deneyimi olarak erek kültürde yerini alabilecektir. Güven, belli bir topluluğu bir arada tutan en önemli değer olduğundan iletişim ediminde birincil önem taşıyan bu değerin yeniden çeviri bağlamında sağlanması çeviri intihali konusunda dikkatli bir çevirmen, okur ve yayınevi kitlesinin oluşmasına katkıda bulunabilecektir.

\footnotetext{
Hakem Değerlendirmesi: Dış bağımsız.

Çıkar Çatışması: Yazar çıkar çatışması bildirmemiştir.

Finansal Destek: Yazar bu çalışma için finansal destek almadığını beyan etmiştir.

Peer-review: Externally peer-reviewed.

Conflict of Interest: The author has no conflict of interest to declare.

Grant Support: The author declared that this study has received no financial support.
}

\section{KAYNAKÇA/REFERENCES}

Berman, A. (1990). La retraduction comme espace de la traduction. Palimpsestes, 4, 1-7.

Chesterman, A. (2000a). A causal model for Translation Studies. Maeve Olahan (ed), Intercultural Faultlines: Research Models in Translation Studies I: Textual and Cognitive Aspects, Manchester: St. Jerome, 15-27. Chesterman, A. (2000b). Memes of Translation: The Spread of Ideas in Translation, John Benjamin.

Çelik, Ö. (2008). Robinson Crusoe'nun Türkçe Çevirileri Bağlamında Çeviride İntihal Olgusu. Çeviri ve Çevirmenliğin Etik Sorunları (Çeviri Etiği Toplantısı 7-8 Aralık 2006 Bildiri Kitabı) içinde, İstanbul: İstanbul Üniversitesi Yayın No: 4739, s.161-170.

Çevirmenler Meslek Birliği. (2007). ÇEVBİR-YAYBİR İntihal İnceleme Komisyonu Sonuç Raporu. http:// www.cevbir.org/yeni/index.php/tr/intihalkomrap, [Erişim: 10.11.2013]

Desmidt, I. (2009). (Re)translation Revisited. Meta LIV, 4, 669-683. 
Eco, U. (1979). Lector in Fabula, Milano: Bompiani.

Ece, A. (2010). Edebiyat Çevirisinin ve edebiyat çevirmeninin izinden. İstanbul: Sel Yayıncıl1k.

Evirgen, Ş. (2008). Çeviride İntihalin Saptanması: Örnek Olarak Montaigne’in “Denemeler”inin Çevirileri. Çeviri ve Çevirmenliğin Etik Sorunları (Çeviri Etiği Toplantısı 7-8 Aralık 2006 Bildiri Kitabı) içinde, İstanbul: İstanbul Üniversitesi Yayın No: 4739, s. 171-177.

Gürçağlar, Ş. T. (2008). Retranslation. Mona Baker (ed.) Routledge Encyclopedia of Translation Studies içinde, $2^{\text {nd }}$ Edition, London and New York: Routledge.

Gürses, S. (2008). Çeviri İntihali: Kültürel Ekosistemin Paraziti. Çeviri ve Çevirmenliğin Etik Sorunları (Çeviri Etiği Toplantısı 7-8 Aralık 2006 Bildiri Kitabı) içinde, İstanbul: İstanbul Üniversitesi Yayın No: 4739, s. $133-146$.

İğrek, M. (2013). 100 Temel Eser Kitapları İntihal Çeviriyi Arttırdı. Zaman Kültür, 1 Aralık 2013. http://www. zaman.com.tr/kultur_100-temel-eser-kitaplari-intihal-ceviriyi-artirdi_2175558.html [Erişim:05.12.13]

Koskinen K., \& Outi, P. (2010). Retranslation. Yves Gambier \& Luc van Doorslaer (editors), Handbook of Translation Studies içinde, John Benjamins Publishing Company, s. 294-297.

Leighton, L. G. (1994). Translation and Plagiarism: Puskin and D.M. Thomas. The Slavic and East European Journal, Vol. 38, No. 1, p. 69-83.

Parlak, B. (2008). Çeviri İntihalleri Bağlamında İlahi Komedi. Çeviri ve Çevirmenliğin Etik Sorunları (Çeviri Etiği Toplantısı 7-8 Aralık 2006 Bildiri Kitabı) içinde, İstanbul: İstanbul Üniversitesi Yayın No: 4739, s. $147-160$.

Parlak, B. (2008). Norm ve Değer İlişkisi Bağlamında Çeviri Etiği. Çeviri ve Çevirmenliğin Etik Sorunları (Çeviri Etiği Toplantısı 7-8 Aralık 2006 Bildiri Kitabı) içinde, İstanbul: İstanbul Üniversitesi Yayın No: 4739, s.121-132.

Perromat-Augustin, K. (2011). Plagiarism: aesthetics or contemporary movement? [online article], 452F Electronic journal of literature and comparative literature, 5, [Erişim :18/11/13]

http://www.452f.com/pdf/numero05/perromat/05_452f_perromat_trad_en.pdf

Pym, A. (1998). Method in translation history. Manchester: St. Jerome.

Sharon, L. D. (2011). Confronting the Retranslation Hypothesis: Flaubert and Sand in the British Literary System. PhD Thesis, University of Edinburgh.

Susam-Sarajeva, Ş. (2000). Multiple-entry visa to travelling theory: Retranslations of literary and cultural theories. Target, 15(1), 1-36.

Turell, M. T. (2004). Textual kidnapping revisited: the case of plagiarism in literary translation. Speech, Language and the Law, 11(1), 1-26. 